\title{
Distribution patterns of riodinid butterflies (Lepidoptera: Riodinidae) from southern Brazil
}

\author{
Ricardo R Siewert ${ }^{1 *}$, Cristiano A Iserhard ${ }^{2}$, Helena P Romanowski ${ }^{1}$, Curtis J Callaghan ${ }^{3}$ and Alfred Moser ${ }^{4}$
}

\begin{abstract}
Background: The aim of this study was to synthesize the knowledge of Riodinidae butterflies (Lepidoptera: Papilionoidea) in Rio Grande do Sul state (RS), southern Brazil, evaluating the role of climatic, topographic, and vegetational variables on the observed patterns of occurrence and distribution of these butterflies in the Pampa and Atlantic Forest biomes. The records of riodinid butterflies in RS were collected from published studies and the examination of museum collections in Brazil.

Results: A total of 97 taxa of Riodinidae were recorded, distributed in 92 municipalities. The NMDS analysis and the Constrained Analysis of Principal Coordinates grouped the municipalities according to the phytogeographic regions and biomes - Pampa and Atlantic Forest domains - in which the species records were made. Distance from the ocean, precipitation and temperature were the environmental variables which most contributed to explain the distribution patterns of these butterflies. The multivariate Mantel correlogram suggests that over short distances, the composition of species shows significant levels of spatial autocorrelation, and as geographic distance increases, these levels tend to present negative values.

Conclusions: The results suggest that the observed distribution pattern of Riodinidae in the different biomes and phytogeographic regions in the extreme southern Brazil could be explained by climatic, environmental variables and geographic distance.
\end{abstract}

Keywords: Atlantic forest; Occurrence; Pampa; Spatial autocorrelation

\section{Background}

The distribution of insects is highly influenced by a combination of factors, such as climate, vegetation and topography (Wolda 1988; Goldsmith 2007; Bonebrake and Deutsch 2012). Environmental heterogeneity can derive from the variation of the abovementioned factors across time and space, shaping the patterns of occurrence and diversity of these organisms. Butterflies are closely associated with a variety of biotic and abiotic variables, being a useful group for environmental diagnosis and identification of priority areas for conservation (Brown and Freitas 2000a). Moreover, butterflies are reasonably easy to sample, some taxa have relatively well-known taxonomy and may be considered a charismatic group. For all these features, some butterfly

\footnotetext{
* Correspondence: ricardo.siewert@gmail.com

'Departamento de Zoologia, Universidade Federal do Rio Grande do Sul, Avenida Bento Gonçalves 9500, Prédio 43435, Sala 229, Porto Alegre, Rio Grande do Sul, Brazil

Full list of author information is available at the end of the article
}

groups can be used as flagships in biodiversity conservation (New 1997; Brown and Freitas 1999; Freitas 2010). However, there is a paucity of knowledge and a lack of studies concerning general patterns of distribution in tropical butterflies on large scales, especially in Brazil (see Bonebrake et al. 2010 for more details).

Riodinid richness is highly concentrated in the neotropics, with $95 \%$ of the species (c.a. 1,300) occurring in this region (DeVries 1997; Hall 2002). These butterflies are generally associated in restricted to specific microhabitats and may be spatially rare with low population densities, even if showing, in some cases, wide distributions (Callaghan 1978; Brown 1992; DeVries 1997). For example, the genus Seco Hall and Harvey 2002 is restricted to xeric habitats (Hall and Harvey 2002a), while some species from Euselasia only occur in wet environments (e.g. Nishida 2010) and most Aricoris species are linked to grasslands habitats in vast areas of South America. Despite being the second most diverse family (after the Nymphalidae), Riodinidae is a poorly studied 
group among the butterflies (Hall and Harvey 2002b). Natural history and basic aspects of its biology, such as life history and morphology, are unknown for most species ( $85 \%$ to $87 \%$, Hall et al. 2004; Kaminski 2008). The little knowledge available, however, points to a high habitat specificity of the riodinid butterflies and the sheer number of species present in a given site may be a good indicator of environmental health.

Brazil is one of the three countries with the largest richness of Neotropical butterflies, with more than 3,200 estimated species (Brown and Freitas 1999). However, there is a lack of inventories, especially taking into account its great diversity of biomes. Most of the surveys are concentrated in the Atlantic Forest domain, and many regions of the Brazilian territory still require much sampling effort (Marini-Filho and Freitas 2011). When compared to other Brazilian states, the butterfly fauna of Rio Grande do Sul, the southernmost state of Brazil, is relatively well known and studied (Santos et al. 2008). In particular, few other parts of the country were ever surveyed since as early as the end of the 19th and beginning of the 20th centuries. Most recently published inventories are related to Atlantic Forest habitats (Teston and Corseuil 1999, 2000, 2002; Corseuil et al. 2004; Iserhard and Romanowski 2004; Giovenardi et al. 2008; Grazia et al. 2008; Bonfantti et al. 2009; Romanowski et al. 2009; Iserhard et al. 2010; Pedrotti et al. 2011; Ritter et al. 2011; Santos et al. 2011; Bellaver et al. 2012; Morais et al. 2012), and the major gaps of information concern the Pampa (native grasslands), a biome restricted in Brazil to its extreme south and which covers about $2 \%$ of its surface, extending through Uruguay and northwest Argentina (Bencke 2009; Pillar et al. 2009), exclusive to austral South America.

This study aimed (1) to compile and upgrade a species list of riodinid of this extreme southern Brazilian state, (2) to identify environmental variables that shape the patterns of occurrence and distribution of Riodinidae in this region, and (3) to compare the species composition of these butterflies among the different phytogeographic regions in Atlantic Forest and Pampa from southern Brazil.

\section{Methods}

\section{Study area}

Rio Grande do Sul state (RS), located in extreme southern Brazil, has an area of 281,748,538 $\mathrm{km}^{2}$ and borders on Uruguay and Argentina (IBGE 2004). The northeast of RS (36\%) is part of the Atlantic Forest biome, the second most endangered forest in the world, with different ecosystems such as Mixed and Dense Ombrophilous Forests and Seasonal Deciduous and Semideciduous Forests (Figure 1). The remainder of the area (64\%) is included in the Pampa biome, comprising the native grasslands of South America and associated ecosystems (Pillar et al. 2009). The climate in RS is subtropical and according to Köppen's classification, is $\mathrm{Cfb}$ in the northeast highland region and in the higher portions of Basaltic Plateau and Serra do Sudeste and Cfa in other regions (Kuinchtner and Buriol 2001).

\section{Data collection}

The records of riodinid butterflies were collected from published studies (Mabilde 1896; Azzará 1978; Biezanko et al. 1978; Ruszczyk 1986; Hall and Harvey 2001, 2002a; Krüger and Silva 2003; Iserhard and Romanowski 2004; Marchiori and Romanowski 2006a, b; Dessuy and Morais 2007; Sackis and Morais 2008; Giovenardi et al. 2008; Bonfantti et al. 2009; Iserhard et al. 2010; Siewert et al. 2010, 2014; Fronza et al. 2011; Ritter et al. 2011; Rosa et al. 2011; Morais et al. 2012; Bellaver et al. 2012; Dolibaina et al. 2013; Dias et al. 2013) and the examination of museum collections in Brazil, as follows: Centro de Pesquisa Agropecuária Clima Temperado da Embrapa (CAMB), Museu de História Natural da Universidade Católica de Pelotas (MUCP), Museu de Ciências Naturais Carlos Ritter (MNCR), and Museu Entomológico Ceslau Biezanko (MECB), in Pelotas, Museu Anchieta de Porto Alegre (MAPA), Museu de Ciências e Tecnologia da Pontifícia Universidade Católica do Rio Grande do Sul (MCTP), Museu de Ciências Naturais da Fundação Zoobotânica do Rio Grande do Sul (MCNZ), Museu Ramiro Gomes Costa da Fundação Estadual de Pesquisa Agropecuária (MRGC) and Coleção de Lepidoptera do Departamento de Zoologia da Universidade Federal do Rio Grande do Sul (CLDZ), in Porto Alegre, Coleção de Lepidoptera Alfred Moser (CLAM), in São Leopoldo, Museu e Arquivo Histórico Professor Hermann Wegermann (MAHP) in Panambi, and Departamento de Zoologia da Universidade Federal do Paraná (DZUP), in Curitiba. The collections of Museu de Zoologia da Universidade Federal de São Paulo, in São Paulo (MZSP), Museu Nacional da Universidade Federal do Rio de Janeiro, in Rio de Janeiro (MNRJ), and Coleção de Lepidoptera do Museu de Zoologia da Universidade Estadual de Campinas, in Campinas (ZUEC), were also consulted but there were no Riodinidae from RS in any of them.

All identifications and nomenclature of museum specimens were checked and revised, and for each specimen, the municipality, geographical coordinates, and reference collection were recorded. As reported by Ferro and Melo (2011), geographical coordinates were not available for most museum specimens, and thus, we used geographical coordinates from the municipality nearest to the point in which the specimen was collected, obtained by the GeoLoc tool for the information system 'splink', available from the Reference Center on Environmental Information (http://splink.cria.org.br/geoloc). The specimens were identified from D'Abrera (1994), comparison 


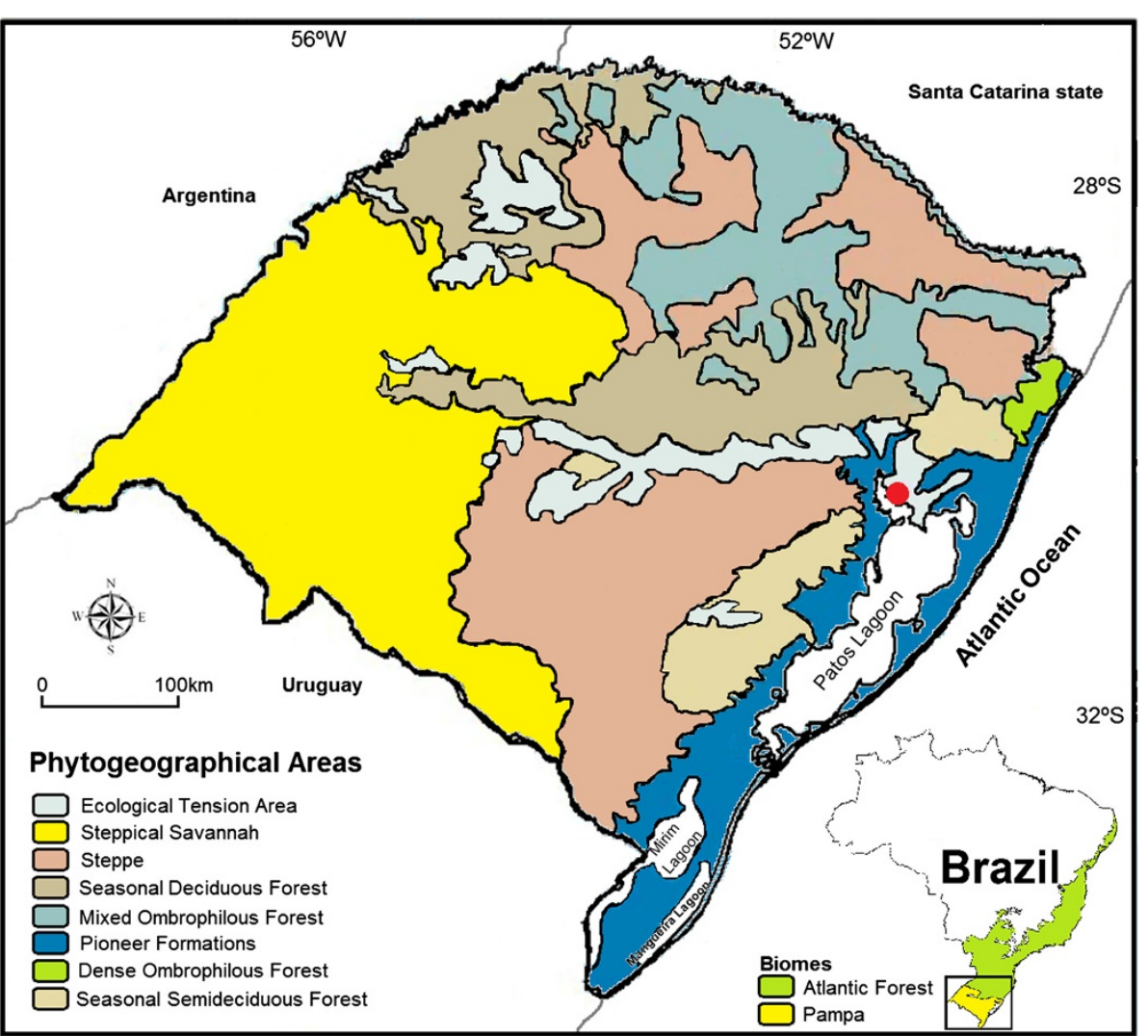

Figure 1 Rio Grande do Sul State and recognized phytogeographical regions. Red spot indicates Porto Alegre, the capital of the State. Phytogeographical regions follow Cordeiro and Hasenack (2009).

with types from the Butterflies of America project (http:// www.butterfliesofamerica.com/L/Neotropical.htm) and by specialists. The nomenclature follows Callaghan and Lamas (2004).

\section{Data analysis}

The dataset used was plotted in cells of $27 \times 27 \mathrm{~km}$ using the Diva-GIS 7.5 software (Hijmans et al. 2001), so that the spatial patterns of species richness through RS could be determined. To verify if the species richness per cell was correlated with the number of sites sampled on a cell, a Spearman correlation was performed.

To reduce the noise in the statistical analysis, we selected the 25 best-sampled municipalities for assessing all the eight phytogeographic regions (according to Cordeiro and Hasenack 2009) and its climatic and geographical combined factors. The similarities in riodinid species composition among the phytogeographic regions were performed through a non-metric multidimensional scaling (NMDS, Clarke 1993), in which the sampling units were the municipalities. The data matrix generated was calculated using the Simpson beta-diversity index $\left(\beta_{\text {sim }}\right)$, which takes into account only the difference in species composition among samples, reducing any variation in sampling effort in different sites (Koleff et al. 2003). To test for differences in riodinid species composition, an analysis of similarities (ANOSIM) based in 10,000 permutations was used (Clarke and Warwick 1994).

To evaluate the effect of climatic and geographical factors on riodinid species composition, five environmental variables were included: (1) average monthly temperature, (2) daily range of temperature, (3) annual precipitation, (4) altitude, and (5) distance from the ocean (a measure of continentality). We choose these variables based on their importance to the description of the structure of lepidopteran assemblages in the Neotropical region (e.g., Brown and Freitas 2000a, b; Ferro and Melo 2011). The climatic variables were selected from the WorldClim database (Hijmans et al. 2005) in a resolution of 2.5 arc min (approximately $5 \mathrm{~km}$ ). The distance to the ocean was obtained through the minimum distance between the coast and the municipalities. A Constrained Analysis of Principal Coordinates (CAPC, Anderson and Willis 2003) was used based on a dissimilarity matrix employing the Simpson beta-diversity index. The significance of the axes generated by CAPC was tested by an ANOVA based in 10,000 permutations (Legendre and Legendre 1998). 
The spatial autocorrelation between sampling sites was assessed using a multivariate Mantel correlogram (Legendre and Legendre 1998; Borcard and Legendre 2012). A matrix based on species composition of each municipality using the Sørensen index as a measure of distance was built. This matrix was evaluated in relation to a geographic distance matrix in which for each municipality, eight distance classes were quantified, and a respective value of Pearson's $R$ statistic was assigned. This analysis was performed to determine whether closest locations were more similar in species composition of Riodinidae, showing a positive autocorrelation, or less similar, showing a negative autocorrelation (Legendre and Legendre 1998). The significance of the correlogram was tested with 10,000 permutations.

The Mantel correlogram was computed with the software Spatial Analysis in Macroecology (SAM) version 4.0 (Rangel et al. 2010), other analyses were performed using the 'vegan' package (Oksanen et al. 2008) on the software $\mathrm{R}$ version 2.15 ( $\mathrm{R}$ Development Core Team 2012).

\section{Results}

A total of 97 taxa (Additional file 1) of Riodinidae recorded from 92 municipalities on RS were gathered (Additional file 2), belonging to Euselasiini (6 spp), Eurybiini (3 spp), Helicopini (1 spp), Mesosemiini (5 spp), Nymphidiini (31 spp), Riodinini (29 spp), Symmachiini (11 spp), and Incertae Sedis (11 spp). Fourteen species are unpublished records, and for each municipality, the richness ranged from 1 to 37 species.
From the total 483 cells $(27 \times 27 \mathrm{~km})$, formed by the grid generated over the area of RS, only 69 presented records of Riodinidae species, highlighting the lack of uniformity in sampling effort (Figure 2). The three richest cells were located in (1) southern (Pelotas and surroundings) belonging to Pampa, and in northeast RS in (2) Maquiné (representing the Atlantic Forest stricto sensu region) and (3) Porto Alegre, São Leopoldo and Viamão in the ecotone of both biomes. Cells in the west and southeast had few records. The observed species richness per cell was correlated with the number of the sampled municipalities $\left(r_{\mathrm{s}}=0.52, p<0.01\right)$.

The faunal composition in areas from the Pampa biome differed from Atlantic Forest sites (Figure 3), grouping Riodinidae according to the phytogeographic regions, especially in Pampa. This difference in species composition is statistically significant $(r=0.56, p<0.01)$. Some exclusive species to native grasslands were recorded, such as Aricoris gauchoana, Seco aphanis, Stichelia dukinfieldia and Zabuella tenellus, Barbicornis basilis ephippium and Stichelia pelotensis were also recorded and are endemic to RS.

Similar results were obtained in the CAPC, which segregates the municipalities between the two biomes and the phytogeographic regions evaluated (Figure 4). The first three axes of the CAPC explained $82 \%$ of the variation on the species composition according to the environmental variables $(p<0.05$; Table 1$)$. Municipalities in the Dense and Mixed Ombrophilous Forests and Seasonal Semideciduous Forest were positively associated with precipitation. Sites with high altitudes were grouped. Distance from the ocean and temperature were

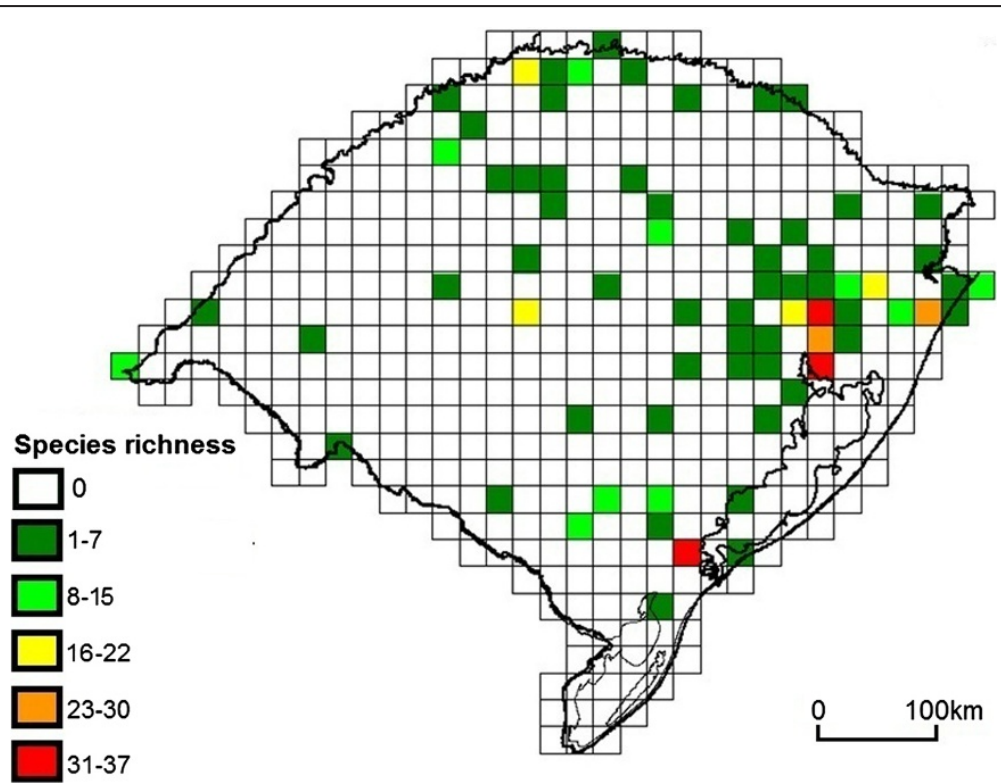

Figure 2 Spatial pattern of Riodinidae species richness recorded in Rio Grande do Sul State, Brazil. 


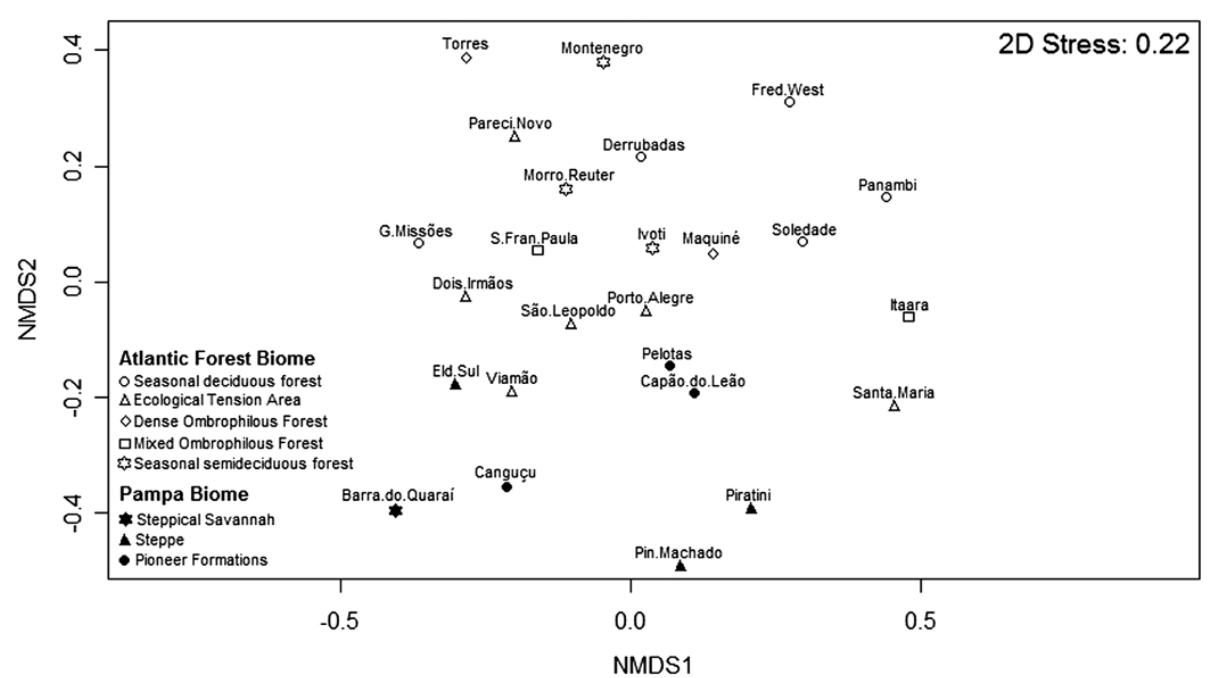

Figure 3 Non-metric multidimensional scaling (NMDS). Based on Simpson beta-diversity index $\left(\beta_{\text {sim }}\right)$ for the Riodinidae species sampled in 25 municipalities in Rio Grande do Sul state, southern Brazil.

opposite to precipitation and altitude, while daily range of temperature was positively associated with grassland habitats and negatively associated with the other variables.

The multivariate Mantel correlogram indicates that species composition and geographical distance were correlated even if not strongly so $\left(r_{\mathrm{M}}=0.40, p<0.01\right)$. Small distances between sites (approximately $90 \mathrm{~km}$ ) have positive values of autocorrelation $(p<0.01)$, followed by a decrease on these values, quickly at first, after stabilizing and then having slightly negative values (Figure 5). This spatial pattern indicates that nearest municipalities have more similar composition of Riodinidae and as the geographical distance grows, an increasing dissimilarity in species composition is observed.

\section{Discussion}

The distribution pattern of Riodinidae in the different biomes and phytogeographic regions in the extreme southern Brazil observed could be explained by climatic, environmental variables and geographic distance. The richness of Riodinidae recorded in this study represents $12.8 \%$ from the estimated total of this butterfly family in Brazil (Brown and Freitas 1999), 7.9\% in the Neotropical region, and $7.5 \%$ in the global fauna (Hall 2002). The

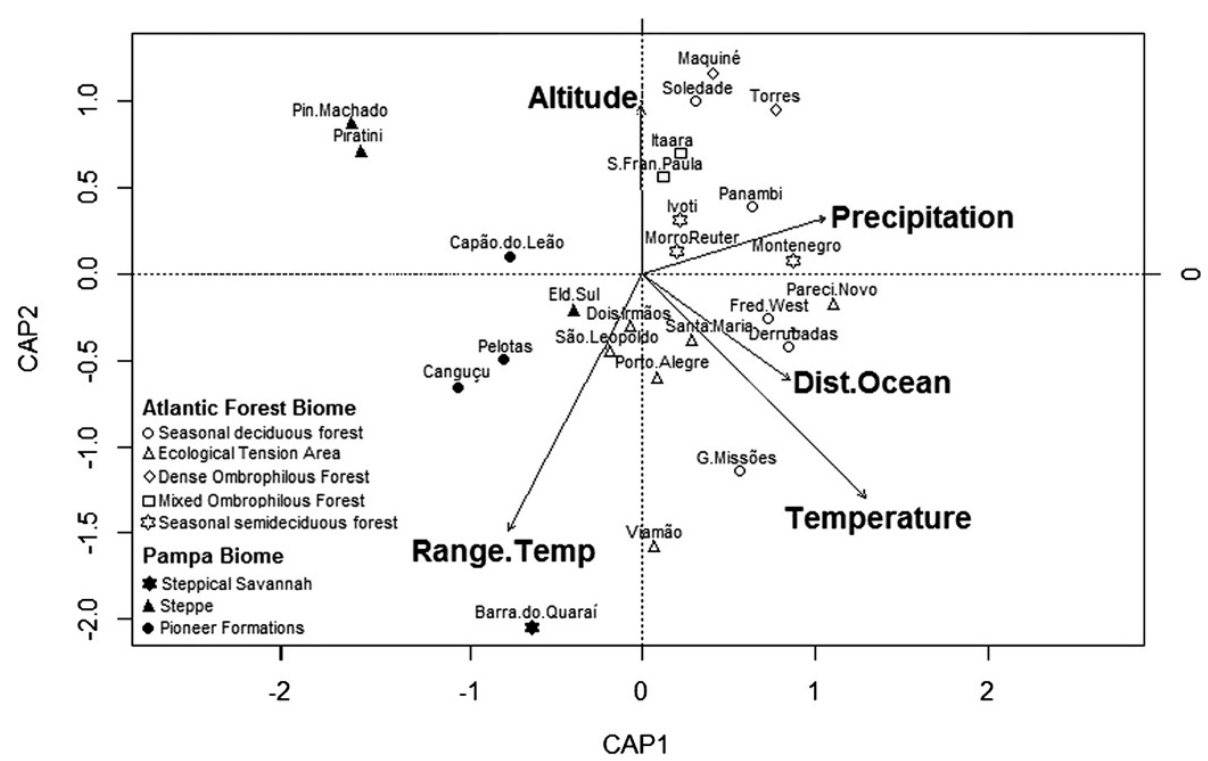

Figure 4 Constrained Analysis of Principal Coordinates (CAPC). Based on Simpson beta-diversity index $\left(\beta_{\text {sim }}\right)$ for the Riodinidae species sampled in 25 municipalities in Rio Grande do Sul state, southern Brazil. 
Table 1 Environmental variables and its correlations in the Constrained Analysis of Principal Coordinates

\begin{tabular}{llll}
\hline Variable & Axis 1 & Axis 2 & Axis 3 \\
\hline Altitude & -0.005 & 0.44 & -0.43 \\
Distance from ocean & 0.39 & -0.28 & -0.84 \\
Annual precipitation & 0.48 & 0.14 & -0.52 \\
Daily range of temperature & -0.35 & -0.67 & -0.65 \\
Average monthly temperature & 0.58 & -0.58 & 0.04 \\
\hline
\end{tabular}

high number of unpublished records (approximately $18 \%$ ) for the extreme southern region in Brazil corroborates the study developed by Morais et al. (2007) with butterflies in austral South America, in which Riodinidae, Lycaenidae, and Hesperiidae are the families which take longer to reach sampling sufficiency. Thus, these are likely to have the larger number of new occurrences to be registered in southern Brazil, and in the Neotropical region as a whole.

The grids which contained the higher number of species richness were located on the Atlantic Forest domain and in the ecotone between this biome and Pampa. On the other hand, the records of Riodinidae in Pampa are quite sparse, leaving significant gaps to be investigated. In general, this scenario is common for all butterfly families present in Pampa (Rosa et al. 2011). An important aspect should be considered: the well-sampled sites are reported in areas with an amount of researchers and established research institutions (mainly represented by universities) near the state capital (Porto Alegre) or their main research project sites (Iserhard and Romanowski 2004; Marchiori and Romanowski 2006a, b; Iserhard et al. 2010; Bellaver et al. 2012). In Brazil, this pattern is similar for all butterfly fauna, in which the counties that contain more inventories and higher values of species richness are located in areas surrounding important research centers, greatly limiting the access and exploitation to few and limited areas (Santos et al. 2008).

The NMDS result showed similar patterns to those found by Ferro and Teston (2009) for the Arctiidae assemblages in the same region in southern Brazil, but in a more restricted scale: grassland environments had a distinct fauna than that occurring in forested areas. In fact, the composition and occurrence of Lepidoptera are strongly associated with gradients of vegetation (e.g., Brown and Gifford 2002; Summerville et al. 2001); although, in this study, most records were concentrated in regions of Atlantic Forest, it was possible to observe differences on the composition of riodinid between Pampa and Atlantic Forest sites. This result is not surprising given that, when compared, these two biomes have very distinct habitats and formations, floristic composition, and structure and architecture of vegetation and suffer influences of different subsets of abiotic factors segregating, in this way, the riodinid fauna.

The riodinid species composition grouped by phytogeographic regions in areas of the Atlantic Forest domain were not well defined, except for sites located on the ecological tension area. The lack of sampling effort in sites on the Seasonal Semideciduous Forests and the occurrence of the most frequent Riodinidae species in all phytogeographic forested regions (not helping to recognize differences in vegetation in this scale of evaluation) are possible explanations for these patterns. In this study, two common riodinid species whose presence indicates an especially rich environment were recorded for the first time in the Atlantic Forest of this Brazilian region: Euselasia zara and Symmachia arion (Brown

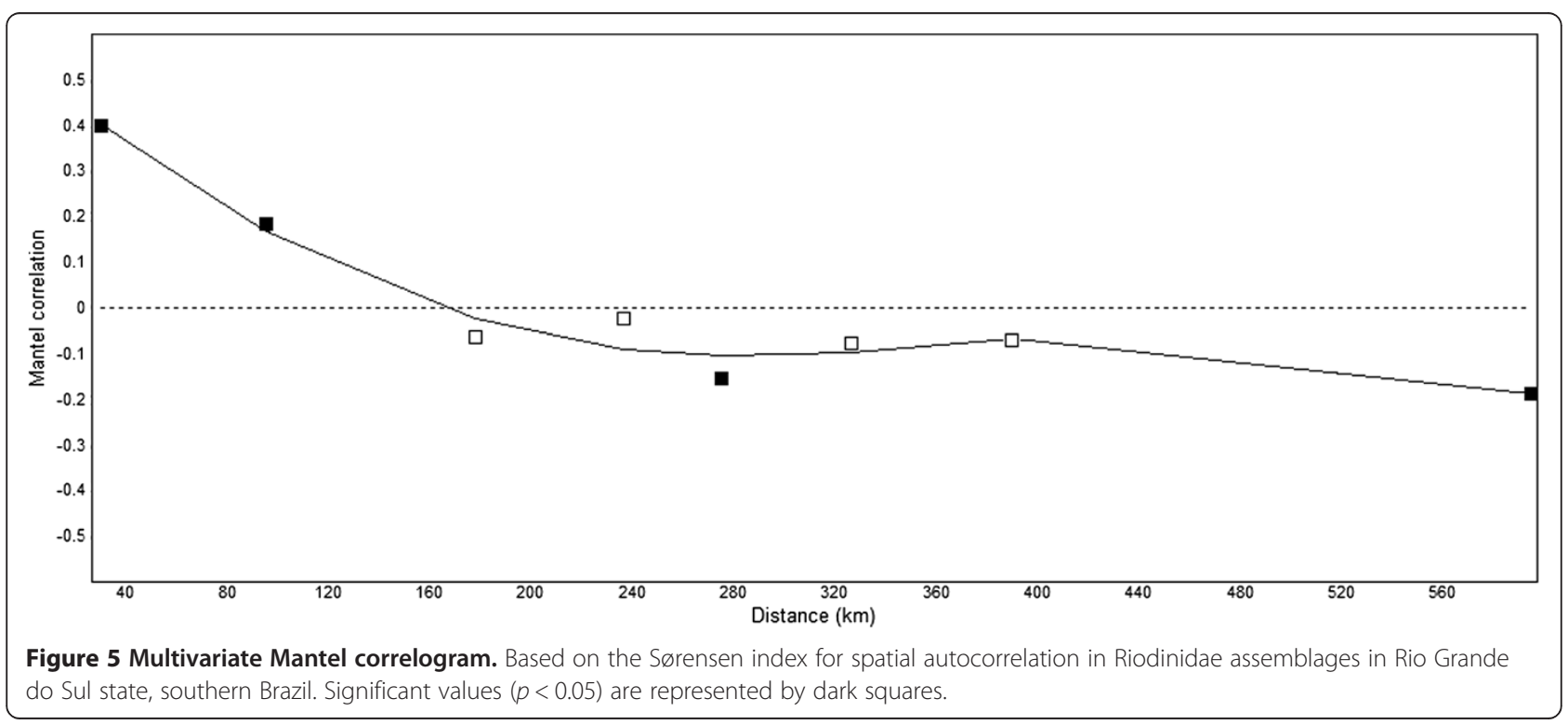


and Freitas 2000b). The Atlantic Forest domain is a highly threatened biome due to changes and depletion of their native habitats over time, and actually less than $7.5 \%$ of their original extension remains, broken into small and sparse fragments (Myers et al. 2000; Ribeiro et al. 2009). Brown and Freitas (2000a) recorded 368 species of Riodinidae for the Brazilian Atlantic Forest, and about $40 \%$ are endemic to this biome, emphasizing the importance of conserving these remaining fragments to the maintenance of biological diversity. On the other hand, the grouping of butterflies according to the phytogeographic regions present in the Pampa indicate a peculiar composition related to each open grassland habitat and to the endemism of some species found in the present study. These results reinforce the fact that different Pampa habitat types are unique and diverse with large levels of endemism and biodiversity (Pillar et al. 2009).

Emphasizing the abovementioned results, an important record related to an endemic species in the Rio Grande do Sul was found: Stichelia pelotensis was collected only twice, through a historical record in the extreme southern region of this state, near the boundaries with Uruguay in the 1950 s and one recent collection (in 2001) from the vicinities of the state capital in a protected area in the Rio Grande do Sul east region, located in the Coastal Plain. Probably, this species is distributed only in this region in Brazil, since records were made in a narrow range concerning the extreme southern Brazilian Coastal Plain in 'Restinga' forest and 'Butiazal' formation, the latter being a peculiar and exclusive physiognomy in this region. These environments have been suffering intense modification due to irregular settlements and building, so their depletion and fragmentation can bring irreversible consequences to riodinid butterflies.

Several species of Riodinidae present a restricted spatial distribution given their population rates being lower than other butterflies and tending to high fluctuations, which make them easily threatened by the loss of native areas (New 1993). In addition, they are difficult to sample in short periods of time. In southern Brazil, the natural grasslands are being increasingly converted into areas for agriculture, silviculture, and livestock grazing. The Pampa biome has less than $0.5 \%$ of its area included in protected areas (Overbeck et al. 2007). Thus, not only Riodinidae but also all butterflies in close association with this vegetation may be threatened, and the first step to their conservation ought to be the creation of new legal protected areas (Overbeck et al. 2007; Dolibaina et al. 2011).

Climatic and geographical factors are important to describe patterns of structure of butterfly communities (Brown and Freitas 2000a). In our study, distance from the ocean, precipitation, and temperature were the most important variables which explain the variation of the riodinid assemblages in the Atlantic Forest. Altitude was another important factor, grouping sites characterized by the presence of the Mixed Ombrophilous Forest (Araucaria angustifolia Forest), a type of vegetation exclusive of the south Brazilian region. In Atlantic Forest, the montane forests, such as Araucaria Forest sites, seem to present a higher similarity on its floristic composition (e.g., Oliveira-Filho and Fontes 2000; Garcia et al. 2009; Urbanetz et al. 2010), which may be influencing the patterns of occurrence of some lepidopteran species (e.g., Brown and Freitas 2000a; Ferro and Melo 2011).

All municipalities in the Pampa biome, in the southern portion of the south region, were associated with the range of temperature. In fact, areas further from the equator present wide ranges of temperature, reflecting a decrease in species along a latitudinal gradient (see Hillebrand 2004). The study area lies in a transition zone between tropical and temperate climate (Overbeck et al. 2007), showing marked seasonality with four defined seasons. The richness of Riodinidae seemed to be correlated with warmer temperatures, presenting high values in Amazonia and in areas of Atlantic Forest in southeast Brazil (Brown 2005). Thus, the lower richness of Riodinidae in Pampa when compared with other sites near the equator, may be associated, beyond the lack of specific inventories, to the influence of a latitudinal gradient.

As geographical distance increases, the similarity in environmental factors decays across landscapes and the species composition of Riodinidae as well (e.g., Nekola and White 1999). The overall shape of the correlogram could be attributed either to a species gradient or to environmental factors (Legendre and Fortin 1989), corroborating the previous multivariate analysis.

It is important to note that our database was constructed mainly with museum data, and in many cases, its use should be carefully interpreted because of the bias regarding the different sampling efforts (Ponder et al. 2001; Graham et al. 2004; Moerman and Estabrook 2006). Similarly, Ferro and Melo (2011) also used museum data to describe the diversity of tiger moths in the Brazilian Atlantic Forest and discussed this aspect. Even so, both their results and ours seem quite robust. The information yielded indicates a structure for the riodinid assemblages of southern Brazil similar to that described for the tropical lepidopteran fauna (e.g., Brown and Freitas 2000b).

\section{Conclusions}

Despite the fact that the extreme southern Brazil has been considered one of the better sampled regions for butterfly surveys (Santos et al. 2008), it is important to emphasize the need to intensify specific and well-sampled inventories. Thus, it is possible to more accurately 
evaluate patterns of structure, distribution, and composition of butterflies, to generate data for larger scales of evaluation in the Neotropical region, reaching the level of macroecology. This study may be seen as reflecting the current knowledge on the Riodinidae fauna in an austral South American region, and we suggest these same variables may also affect the distribution of the taxon in other parts of the neotropics as well. The data on Riodinidae species distribution show variable degrees of endemism in unprotected areas, providing subsidies to a better assessment directed towards conservation schemes and public policies to justify the maintenance of protected areas and, mainly, the proposal and creation of others.

\section{Additional files}

Additional file 1: Riodinidae species list from Rio Grande do Sul state, southern Brazil. * See Additional file 2 for municipality codes. ** Reference sources: ' $A$ Azzará 1978, 'bellaver et al. 2012, 'Biezanko et al. 1978, ${ }^{d}$ Bonfantti et al. 2009, ${ }^{e}$ Dessuy and Morais 2007, 'Giovenardi et al. 2008, ${ }^{9}$ Hall and Harvey 2001, ${ }^{\text {hHall }}$ and Harvey 2002a, IIserhard and

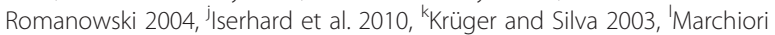
and Romanowski 2006a, ${ }^{m}$ Marchiori and Romanowski 2006b, " Morais et al. 2012, ${ }^{\circ}$ Ritter et al. 2011, ${ }^{\circ}$ Sackis and Morais 2008, ${ }^{9}$ Rosa et al. 2011, 'Dolibaina et al. 2013, 'Dias et al. 2013, ${ }^{\text {'S }}$ iewert et al. 2014. *** See text for museum acronyms. \# Unpublished records for Rio Grande do Sul state.

Additional file 2: Municipalities, phytogeographic region and geographical coordinates from Rio Grande do Sul state, southern Brazil. *According to Cordeiro and Hasenack (2009). P, Pampa Biome; AF, Atlantic Forest Biome.

\section{Competing interests}

The authors declare that they have no competing interests.

\section{Authors' contributions}

RS carried out the design of the study and performed the data collection, identification of all material, the statistical analyses, and drafting of the manuscript. Cl contributed in the statistical analyses and drafting of the manuscript. HR helped in several aspects along this work, as well as acting in the coordination. CC participated in the identification of the material, data collection, and discussion. AM participated in the data collection. All authors read and approved the final manuscript.

\section{Acknowledgements}

We are grateful to Olaf HH Mielke (DZUP), Eduardo JE Silva (MECB), Gervásio S Carvalho (MCTP), Maria Helena S Vaz (MUCP), Mirtes Melo (CAMB), César J Drehmer (MNCR), Vera Regina S Wolff (MRCG), Têmia Wehrmann (MAHP), Fernando Meyer (MAPA), and Maria Helena M Galileo (MCNZ) for providing access to the collections and to Milton S Mendonça Jr, Viviane G Ferro, Márcio B Martins and the two anonymous reviewers for the critical reading of the manuscript. We are also in debt to Jason Hall, Lucas A Kaminski, Diego R Dolibaina, and Fernando MS Dias for their essential help in the identification and information on some specimens. RRS received a master fellowship from the CAPES. HPR received a research fellowship from CNPq (Proc No. 307635/2010-4). CAl received a post-doctoral fellowship from Fundação de Amparo a Pesquisa do Estado de São Paulo (Fapesp - 2011/ 08433-8). This paper is part of the Pampa e Mata Atlântica Sul subproject of the Redelep "Rede Nacional de Pesquisa e Conservação de Lepidópteros" SISBIOTA-Brasil/CNPq (563332/2010-7).

\section{Author details}

'Departamento de Zoologia, Universidade Federal do Rio Grande do Sul, Avenida Bento Gonçalves 9500, Prédio 43435, Sala 229, Porto Alegre, Rio Grande do Sul, Brazil. '2Departamento de Ecologia, Zoologia e Genética, Instituto de Biologia, Universidade Federal de Pelotas, Caixa Postal 354,
Pelotas, Rio Grande do Sul, Brazil. ${ }^{3}$ Casa Picapau, Floresta de la Sabana, Carrera 7, 237-04 Bogotá, Colombia. ${ }^{4}$ Avenida Rotermund 1045, São Leopoldo, Rio Grande do Sul, Brazil.

Received: 14 October 2013 Accepted: 27 February 2014

Published: 12 March 2014

\section{References}

Anderson MJ, Willis TJ (2003) Canonical analysis of principal coordinates: a useful method of constrained ordination for ecology. Ecology 84:511-525

Azzará ML (1978) Revisão do gênero Barbicornis Godart, 1824 (Lepidoptera, Lycaenidae, Riodininae). Acta Biol Parana 7:23-69

Bellaver JM, Iserhard CA, Santos JP, Silva AK, Torres M, Siewert RR, Moser A, Romanowski HP (2012) Borboletas (Lepidoptera: Papilionoidea e Hesperioidea) de Matas Paludosas e Matas de Restinga da Planície Costeira da região Sul do Brasil. Biota Neotrop 12(4):181-190

Bencke GA (2009) Diversidade e conservação da fauna dos campos do sul do Brasil. In: Pillar VP, Müller SC, Castilhos ZMS, Jacques AVA (eds) Campos Sulinos: Conservação e Uso Sustentável da Biodiversidade. Ministério do Meio Ambiente, Brasília, pp 101-121

Biezanko CM, Mielke OHH, Wedderhoff A (1978) Contribuição ao estudo faunístico dos Riodinidae do Rio Grande do Sul, Brasil (Lepidoptera). Acta Biol Parana 7(1/4):7-22

Bonebrake TC, Deutsch CA (2012) Climate heterogeneity modulates impact of warming on tropical insects. Ecology 93(3):449-455

Bonebrake TC, Ponisio LC, Boggs CL, Ehrlich PR (2010) More than just indicators: a review of tropical butterfly ecology and conservation. Biol Conserv 143:1831-1841

Bonfantti D, Di Mare RA, Giovenardi R (2009) Butterflies (Lepidoptera: Papilionoidea e Hesperioidea) from two forest fragments in northern Rio Grande do Sul, Brazil. Checklist 5(4):819-829

Borcard D, Legendre P (2012) Is the Mantel correlogram powerful enough to be useful in ecological analysis? A simulation study. Ecology 93:1473-1481

Brown KS Jr (1992) Borboletas da Serra do Japi: diversidade, hábitats, recursos alimentares e variação temporal. In: Morellato LPC (ed) História Natural da Serra do Japi: Ecologia e preservação de uma área florestal no sudeste do Brasil. Editora da UNICAMP, Campinas, pp 142-187

Brown KS Jr (2005) Geological, evolutionary and ecological bases of the diversification of Neotropical butterflies: implications for conservation. In: Bermingham E, Dick CW, Moritz C (eds) Tropical rainforests: past, present and future. University of Chicago Press, Chicago, pp 166-201

Brown KS Jr, Freitas AVL (1999) Lepidoptera. In: Brandão CRF, Cancello ED (eds) Biodiversidade do Estado de São Paulo. Brasil. Invertebrados Terrestres. FAPESP, São Paulo, pp 225-245

Brown KS Jr, Freitas AVL (2000a) Atlantic Forest butterflies: indicators for landscape conservation. Biotropica 32:934-956

Brown KS Jr, Freitas AVL (2000b) Diversidade de Lepidoptera em Santa Teresa, Espírito Santo. Bol Mus Mello Leitão 11(12):71-118

Brown KS Jr, Gifford DR (2002) Lepidoptera in the cerrado landscape and the conservation of vegetation, soil and topographical mosaics. In: Oliveira PS, Marquis RS (eds) The Cerrados of Brazil: ecology and natural history of a Neotropical savanna. Columbia University Press, New York, pp 201-217

Callaghan CJ (1978) Studies on restinga butterflies. II. Notes on the population structure of Menander felsina (Riodinidae). J Lepid Soc 32:37-48

Callaghan CJ, Lamas G (2004) Riodinidae. In: Lamas G (ed) Atlas of Neotropical Lepidoptera: Checklist: Part 4a Hesperioidea - Papilionoidea. Scientific Publishers, Gainesville, pp 141-170

Clarke KR (1993) Non-parametric multivariate analyses of changes in community structure. Aust J Ecol 18:117-143

Clarke KR, Warwick RM (1994) Similarity-based testing for community pattern: the two-way layout with no replication. Mar Biol 118:167-176

Cordeiro JLP, Hasenack H (2009) Cobertura vegetal atual do Rio Grande do Sul. In: Pillar VP, Müller SC, Castilhos ZMS, Jacques AVA (eds) Campos Sulinos: Conservação e Uso Sustentável da Biodiversidade. Ministério do Meio Ambiente, Brasilia, pp 285-299

Corseuil E, Quadros FC, Teston JA, Moser A (2004) Borboletas (Lepidoptera: Papilionoidea e Hesperioidea) coletadas no Centro de Pesquisa e Conservação da Natureza Pró-Mata. 4: Lycaenidae. Div Mus Ciênc Tecnol PUCRS 9:65-70

D'Abrera B (1994) Butterflies of the Neotropical region. Part VI, Riodinidae, Hill House, Victoria 
Dessuy MB, Morais ABB (2007) Diversidade de Borboletas (Lepidoptera, Papilionoidea e Hesperioidea) em fragmentos de Floresta Estacional Decidual em Santa Maria, Rio Grande do Sul, Brasil. Rev Bras Zool 24(1):108-120

DeVries PJ (1997) The butterflies of Costa Rica and their natural history II: Riodinidae. Princeton University, New Jersey

Dias FMS, Dolibaina DR, Mielke OHH, Casagrande MM (2013) Revision of the genus Stichelia Zikán (Riodinidae: Riodininae: Symmachiini), with the description of a new species from southern Brazil. Zootaxa 3693(4):579-593

Dolibaina DR, Mielke OHH, Casagrande MM (2011) Borboletas (Papilionoidea e Hesperioidea) de Guarapuava e arredores, Paraná, Brasil: um inventário com base em 63 anos de registros. Biota Neotrop 11(1):341-354

Dolibaina DR, Dias FMS, Mielke OHH, Casagrande MM (2013) Taxonomy of the 'Synargis axenus complex' belonging to the 'Synargis regulus' species group, with a phylogenetic reassessment of the genus Synargis Hübner, 1819 (Lepidoptera: Riodinidae: Nymphidiini). Zool J Linn Soc Lond 168:427-451

Ferro VG, Teston JA (2009) Composição de espécies de Arctiidae (Lepidoptera) no sul do Brasil: relação entre tipos de vegetação e entre a configuração espacial do hábitat. Rev Bras Entomol 53(2):278-286

Ferro VG, Melo AS (2011) Diversity of tiger moths in a Neotropical hotspot: determinants of species composition and identification of biogeographic units. J Insect Conserv 15:643-651

Freitas AVL (2010) Impactos potenciais das mudanças propostas no Código Florestal Brasileiro sobre as borboletas. Biota Neotrop 10(4):53-58

Fronza E, Specht A, Corseuil E (2011) Butterflies and moths (Insecta: Lepidoptera) associated with erva-mate, the South American Holly (llex paraguariensis St. Hil.), in Rio Grande do Sul, Brazil. Checklist 7(4):496-504

Garcia RJF, Longhi-Wagner HM, Pirani JR, Meirelles ST (2009) A contribution to the phytogeography of Brazilian campos: an analysis based on Poaceae. Rev Bras Bot 32(4):703-713

Giovenardi R, Di Mare RA, Sponchado J, Roani S, Jacomassa FAF, Jung AB, Porn MA (2008) Diversidade de Lepidoptera (Papilionoidea e Hesperioidea) em dois fragmentos de floresta no município de Frederico Westphalen, Rio grande do Sul, Brasil. Rev Bras Entomol 52:599-605

Goldsmith S (2007) Density of longhorned beetles (Coleoptera: Cerambycidae) differs at different elevations in Hawaiian Montane Forest. Southwest Nat 52(3):364-370

Graham CH, Ferrier S, Huettman F, Moritz C, Peterson AT (2004) New developments in museum-based informatics and applications in biodiversity analysis. Trends Ecol Evol 19:497-503

Grazia J, Romanowski HP, Araújo PB, Schwertner CF, Iserhard CA, Moura LA, Ferro VG (2008) Artrópodos terrestres. In: Bond-Buckup G (ed) Biodiversidade dos Campos de Cima da Serra. Libretos, Porto Alegre, pp 76-97

Hall JPW (2002) Phylogeny of the riodinid butterfly subtribe Theopeina (Lepidoptera: Riodinidae: Nymphidiini). Syst Entomol 27:139-167

Hall JPW, Harvey DJ (2001) A phylogenetic analysis of the Neotropical riodinid butterfly genera Juditha, Lemonias, Thisbe and Uraneis, with a revision of Juditha (Lepidoptera: Riodinidae: Nymphidiini). Syst Entomol 26:453-490

Hall JPW, Harvey DJ (2002a) A revision of the Neotropical butterfly genus Seco Hall and Harvey (Lepidoptera: Riodinidae). P Entomol Soc Wash 104(4):941-947

Hall JPW, Harvey DJ (2002b) The phylogeography of Amazonia revisited: new evidence from riodinid butterflies. Evolution 56(7):1489-1497

Hall JPW, Harvey DJ, Janzen DH (2004) Life history of Calydna sturnula with review of larval and pupal balloon setae in the Riodinidae (Lepidoptera). Ann Entomol Soc Am 97:310-321

Hijmans RJ, Cruz M, Rojas E, Guarino L (2001) DIVAGIS, version 7.5. A geographic information system for the management and analysis of genetic resources data. Available at http://www.diva-gis.org. Accessed 24 Apr 2013

Hijmans RJ, Cameron SE, Parra JL, Jones PG, Jarvis A (2005) Very high resolution interpolated climate surfaces for global land areas. Int J Climatol 25:1965-1978

Hillebrand $\mathrm{H}$ (2004) On the generality of the latitudinal diversity gradient. Am Nat 163(2):192-211

IBGE (2004) Mapa de Vegetação do Brasil. Available at http://www.ibge.gov.br/ home/presidencia/noticias/21052004biomashtml.shtm. Accessed 12 Dec 2012

Iserhard CA, Romanowski HP (2004) Lista de espécies de borboletas (Lepidoptera, Papilionoidea e Hesperioidea) da região do vale do rio Maquiné, Rio Grande do Sul, Brasil. Rev Bras Zool 21(3):649-662

Iserhard CA, Quadros MT, Romanowski HP, Mendonça-Jr MS (2010) Occurrence of butterflies (Lepidoptera: Papilionoidea and Hesperioidea) in different habitats at the Araucaria Moist Forest and the Grasslands in the Basaltic Highlands in Southern Brazil. Biota Neotrop 10:309-320
Kaminski LA (2008) Immature stages of Caria plutargus (Lepidoptera: Riodinidae), with discussion on the behavioral and morphological defensive traits in nonmyrmecophilous riodinid butterflies. Ann Entomol Soc Am 101(5):906-914

Koleff P, Gaston KJ, Lennon JJ (2003) Measuring beta diversity for presenceabsence data. J Anim Ecol 72:367-382

Krüger CP, Silva EJE (2003) Papilionoidea (Lepidoptera) de Pelotas e seus arredores, Rio Grande do Sul, Brasil. Entomol Vectores 10(1):31-45

Kuinchtner A, Buriol GA (2001) Clima do Estado do Rio Grande do Sul segundo a classificação climática de Köppen e Thornthwaite. Discip Sci 2:171-182

Legendre P, Fortin MJ (1989) Spatial pattern and ecological analysis. Vegetatio 80:107-138

Legendre P, Legendre L (1998) Numerical ecology. Elsevier, Amsterdan

Mabilde AP (1896) Guia practica para os principiantes colecionadores de insectos, contendo a descripção fiel de perto de mil borboletas com 280 figuras lythographadas em tamanho, formas e desenhos conforme o natural. Estudo sobre a vida de insectos do Rio Grande do Sul e sobre a caça, classificação e a conservação de uma collecção, mais ou menos regular. Gundlach Schuldt, Porto Alegre

Marchiori MO, Romanowski HP (2006a) Species composition and diel variation of a butterfly taxocene (Lepidoptera: Papilionoidea and Hesperioidea) in a restinga wood at Itapuã State Park, Southern Brazil. Rev Bras Zool 23(2):443-454

Marchiori MO, Romanowski HP (2006b) Borboletas (Lepidoptera, Papilionoidea e Hesperioidea) do Parque Estadual do Espinilho e entorno, Rio Grande do Sul, Brasil. Rev Bras Zool 23(4):1029-1037

Marini-Filho OJ, Freitas AVL (2011) Plano de Ação Nacional para a Conservação dos Lepidópteros Ameaçados de Extinção. Instituto Chico Mendes de Conservação da. Biodiversidade, Brasília

Moerman DE, Estabrook GF (2006) The botanist effect: counties with maximal species richness tend to be home to universities and botanists. J Biogeogr 33:1969-1974

Morais ABB, Romanowski HP, Iserhard CA, Marchiori MO, Segui R (2007) Mariposas del Sur de Sudamérica (Lepidoptera: Hesperioidea y Papilionoidea). Cienc Ambient 35:29-46

Morais ABB, Lemes R, Ritter CD (2012) Borboletas (Lepidoptera: Hesperioidea e Papilionoidea) de Val de Serra, região central do Rio Grande do Sul, Brasil. Biota Neotrop 12(2):175-183

Myers N, Mittermeier RA, Mittermeier CG, Fonseca GAB, Kent J (2000) Biodiversity hotspots for conservation priorities. Nature 403:853-858

Nekola JC, White PS (1999) The distance decay of similarity in biogeography and ecology. J Biogeogr 26(4):867-878

New TR (1993) Conservation biology of the Lycaenidae (Butterflies). IUCN, Gland New TR (1997) Butterfly conservation. Oxford University Press, New York

Nishida K (2010) Description of the immature stages and life history of Euselasia (Lepidoptera: Riodinidae) on Miconia (Melastomataceae) in Costa Rica. Zootaxa 2466:1-74

Oksanen J, Kindt R, Legendre P, O'Hara R, Simpson GL, Stevens MHH (2008) vegan: community ecology package. $\mathrm{R}$ package version 1.13-0. Available at http://vegan.r-forge.r-project.org. Accessed 24 Apr 2013

Oliveira-Filho AT, Fontes MAL (2000) Patterns of floristic differentiation among Atlantic Forests in Southeastern Brazil and the influence of climate. Biotropica 32(4b):793-810

Overbeck GE, Muller SC, Fidelis A, Pfadenhauer J, Pillar VD, Blanco CC, Boldrini II, Both R, Forneck ED (2007) Brazil's neglected biome: the South Brazilian Campos. Perspect Plant Ecol Evol Syst 9:101-116

Pedrotti VS, Barros MP, Romanowski HP, Iserhard CA (2011) Occurrence of fruit-feeding butterflies (Lepidoptera: Nymphalidae) in a fragment of Araucaria Moist Forest in Rio Grande do Sul State, Brazil. Biota Neotrop 11(1):385-390

Pillar VP, Müller SC, Castilhos ZSM, Jacques AVA (2009) Campos Sulinos - conservação e uso sustentável da biodiversidade. Ministério do Meio Ambiente, Brasília

Ponder WF, Carter GA, Flemons P, Chapman RR (2001) Evaluation of museum collection data for use in biodiversity assessment. Conserv Biol 15(3):648-657

R Development Core Team (2012) R: a language and environment for statistical computing. Available at http://www.r-project.org. Accessed 24 Apr 2013

Rangel TF, Diniz-Filho JAF, Bini LM (2010) SAM: a comprehensive application for Spatial Analysis in Macroecology. Ecography 33:46-50

Ribeiro MC, Metzger JP, Martensen AC, Ponzoni FJ, Hirota MM (2009) The Brazilian Atlantic Forest: how much is left, and how is the remaining forest distributed? Implications for conservation. Biol Conserv 142:1141-1153 
Ritter CD, Lemes R, Morais ABB, Dambros CS (2011) Butterflies (Lepidoptera: Hesperioidea and Papilionoidea) from Mixed Ombrophilous Forest fragments, Rio Grande do Sul, Brazil. Biota Neotrop 11(1):361-368

Romanowski HP, Iserhard CA, Hartz SM (2009) Borboletas da floresta com araucária. In: Fonseca CR, Souza AF, Dutra TL, Leal-Zanchet AM, Backes A, Ganade G (eds) Floresta com araucária: ecologia, conservação e desenvolvimento sustentável. Holos Editora, Ribeirão Preto

Rosa PLP, Chiva EQ, Iserhard CA (2011) Borboletas (Lepidoptera: Papilionoidea e Hesperioidea) do Sudoeste do Pampa Brasileiro, Uruguaiana, Rio Grande do Sul, Brasil. Biota Neotrop 11:1-6

Ruszczyk A (1986) Ecologia urbana de borboletas, I. O gradiente de urbanização e a fauna de Porto Alegre, RS. Rev Bras Biol 46(4):675-688

Sackis JD, Morais ABB (2008) Borboletas (Lepidoptera: Hesperioidea e Papilionoidea) do Campus da Universidade Federal de Santa Maria, Santa Maria, Rio Grande do Sul. Biota Neotrop 8(1):151-158

Santos EC, Mielke OHH, Casagrande MM (2008) Butterfly inventories in Brazil: the state of art and the priority-areas model research aiming at conservation. Nat Conserv 6:176-198

Santos JP, Iserhard CA, Teixeira MO, Romanowski HP (2011) Fruit-feeding butterflies guide of subtropical Atlantic Forest and Araucaria Moist Forest in State of Rio Grande do Sul, Brazil. Biota Neotrop 11(3):253-274

Siewert RR, Silva EJE, Marques LL (2010) Catálogo do acervo de borboletas (Lepidoptera: Papilionoidea) depositadas no Museu de História Natural da Universidade Católica de Pelotas, Rio Grande do Sul, Brasil. Entomobrasilis 3(3):77-84

Siewert RR, Dolibaina DR, Mielke OHH, Casagrande MM, Moser A (2014) A new species of Aricoris Westwood, [1851] belonging to "chilensis" group (Lepidoptera: Riodinidae). Zootaxa 3764(4):495-500

Summerville KS, Metzler EH, Crist TO (2001) Diversity of Lepidoptera in Ohio forests at local and regional scales: how heterogeneous is the fauna? Ann Entomol Soc Am 94(4):583-591

Teston JA, Corseuil E (1999) Borboletas (Lepidoptera, Rhopalocera) Ocorrentes no Centro de Pesquisas e Conservação da Natureza Pró-Mata. 1. Papilionidae. Div Mus Ciênc Tecnol PUCRS 4:217-228

Teston JA, Corseuil E (2000) Borboletas (Lepidoptera, Rhopalocera) ocorrentes no Centro de Pesquisas e Conservação da Natureza Pró-Mata. 2. Pieridae. Div Mus Ciênc Tecnol PUCRS 5:143-155

Teston JA, Corseuil E (2002) Borboletas (Lepidoptera, Rhopalocera) ocorrentes no Centro de Pesquisas e Conservação da Natureza Pró-Mata. 3: Nymphalidae. Div Mus Ciênc Tecnol PUCRS 7:1-20

Urbanetz C, Tamashiro JY, Kinoshita LS (2010) Floristic composition and similarity analysis of an Atlantic rain forest fragment in Cananéia, São Paulo State, Brazil. Rev Bras Bot 33(4):639-651

Wolda H (1988) Insect seasonality: why? Ann Rev Ecol Syst 19:1-18

\section{doi:10.1186/1810-522X-53-15}

Cite this article as: Siewert et al.: Distribution patterns of riodinid butterflies (Lepidoptera: Riodinidae) from southern Brazil. Zoological Studies 2014 53:15

\section{Submit your manuscript to a SpringerOpen ${ }^{\circ}$ journal and benefit from:}

- Convenient online submission

- Rigorous peer review

- Immediate publication on acceptance

- Open access: articles freely available online

- High visibility within the field

- Retaining the copyright to your article

Submit your next manuscript at $\gg$ springeropen.com 